\begin{tabular}{c}
\hline KEMAS 15 (1) (2019) 124-130 \\
Jurnal Kesehatan Masyarakat
\end{tabular}

\title{
Ecological Study on Factors Related to the Mortality of Rabies in North Sulawesi Province in 2015 to 2017
}

\author{
Noer Syafiiah Tiarma, Putri Bungsu Machmud ${ }^{\varpi}$ \\ Departement of Epidemiology, Faculty of Public Health, University of Indonesia
}

\begin{tabular}{l} 
Article Info \\
\hline Article History: \\
Submitted May 2019 \\
Accepted July 2019 \\
Published July 2019 \\
\hline Keywords: \\
Rabies, Ecology, \\
Correlation, Mortality, \\
Sulawesi \\
\hline DOI \\
https://doi.org/10.15294/ \\
kemas.v15i1.19168
\end{tabular}

\section{Introduction}

One common but deadly zoonotic disease is rabies. Rabies or mad dog disease is an acute infectious disease that attacks the central nervous system (Kementerian Kesehatan RI, 2017). Rabies is a disease originating from lyssavirus. The word "lyssavirus" comes from the Greek word which means to go berserk. This virus can attack animals such as dog, cat, ape, and fox, but it can also attacks human. When the rabies virus enters human body, the incubation period depends on factors that influence the development of rabies. These factors consist of the presence or absence of bite marks, the location of the bite that is close to the central nervous system (shoulders, neck, head), the number of injuries, or the number of viruses that enter the body, etc (Kementerian
Kesehatan RI, 2016). However, in general, the incubation period varies from a few days to several months, up to several years (World Health Organization, 2013).

Unfortunately, until now there is no specific treatment anywhere in the world for rabies, which make classic rabies cases in human still has almost a $100 \%$ case fatality rate (World Health Organization, 2013). According to the data from World Health Organization, nearly 55,000 deaths due to rabies have been reported worldwide. Rabies in human is still an important global problem, because of the high mortality. (Tenzin, et al., 2011).

Children aged 5-15 years represent 40\% of people who are bitten by rabies vectors in endemic areas, and unfortunately, these events are not recognized and not reported adequately

\footnotetext{
$\triangle$ Correspondence Address:

Departement of Epidemiology, Faculty of Public Health, University of Indonesia

Email : putri.bungsu10@ui.ac.id 
(SEARO World Health Organization, 2012). Nearly $95 \%$ of human rabies cases occur in developing countries in Asia and Sub Saharan Africa (Hampson K, et al., 2015). Therefore, 12 million Asians are estimated to receive PEP every year. Indonesia has 25 provinces with high cases of Transmitted Rabies Animal Bites (TRAB) (Kementerian Kesehatan RI, 2016).

The number of cases is dominated by 3 provinces that contribute to the most of the TRAB, namely Bali, NTT, and North Sulawesi (Kementerian Kesehatan RI, 2018). The biggest contributor of rabies mortality in Indonesia is always North Sulawesi. In 2013-2017, North Sulawesi has always been ranked in the top of 25 provinces that have not been free of rabies in Indonesia (Kementerian Kesehatan RI, 2018). This is certainly a big question, what are the factors that influence the occurrence of death cases due to rabies in North Sulawesi Province. The researcher wanted to understand the correlation of several factors which contribute to the incidence of rabies in North Sulawesi Province.

\section{Method}

This study was an observational study with time and group comparative ecological design (mixed study). It took place in North Sulawesi which consisted of 15 regencies/cities within a period of three years (2015-2017). The dependent variable in the study was the incidence ofdeath due to rabies in North Sulawesi Province in 2017. Meanwhile, the independent variables were sex ratio, education, population density, workforce against working age, number of health workers, health care facilities, wound washing coverage, and VAR coverage. The data were acquired from routine rabies surveillance from the Ministry of Health and data from the Central Bureau of Statistics. This study used total sampling formula, therefore it used all existing regencies/cities. This indicates that all samples are included in the study and there are no excluded data. The data were analyzed using SPSS version 20. Univariate analysis was used to describe the cases, then, linear regression was used to see the strength of the relationship (r) and statistical relationships that occurred. The value of $\mathrm{p}<0.05$ was considered significant. This study used aggregate data, hence, ecological fallacy is likely to occur. Therefore, this study will not generalize the event at individual level. This study has received ethical permission from Faculty of Public Health, University of Indonesia with ethical numbers 791 / UN2.F10 / PPM.00.02 / 2018.

\section{Results and Discussion}

Each independent and dependent variables in this study were tested for its normality using non-parametric statistics, namely Kolmogorov Smirnov test. If the $\mathrm{p}$-value exceeded the normal threshold ( $\mathrm{p}$ $>0.005)$ then the variables were categorized as normal, otherwise they were categorized as abnormal. Based from the normality test, it was found that three variables were categorized as normal (Anti-Rabies Vaccine coverage, sex ratio, and the ratio of health workers), while the others were not.

The results of univariate analysis is described in table 1.

Analysis of the independent variables on

Table 1. Univariate Analysis of Rabies Mortality, Anti Rabies Vaccine, and Demographic Characteristics

\begin{tabular}{llllll}
\hline Variable & Min & Max & Mean & SD & $95 \%$ CI \\
\hline Rabies Mortality & 0,00 & 3.21 & 0.84 & 1.02 & $0.53-1.15$ \\
Anti-Rabies Vaccine (ARV) & 20,1 & 102 & 57.5 & 22.4 & $50.7-64.2$ \\
Coverage & 97.0 & 110 & 104 & 3.21 & $103.5-105.5$ \\
Sex Ratio & 0.00 & 1.46 & 0.30 & 0.32 & $0.20-0.40$ \\
Education & 34.6 & 2740.00 & 526.9960 & 792.01540 & $289.0-764.9$ \\
Population Density &, 005 & 7.98 & 2.39 & 2.24 & $1.72-3.07$ \\
Health Workers Ratio & 4.95 & 260 & 45.6 & 792 & $28.1-63.2$ \\
Healthcare Facility Ratio & & & & &
\end{tabular}


Noer Syafiiah T \& Putri Bungsu M / Ecological Study on Factors Related to the Mortality of Rabies

Table 2. Correlation and Regression Analysis on Independent Variable with Rabies Mortality

\begin{tabular}{|c|c|c|c|c|}
\hline Variables & $\mathrm{R}$ & $\mathrm{R} 2$ & Line Equation & $P$ value \\
\hline $\begin{array}{l}\text { Anti-Rabies Vaccine } \\
\text { (ARV) Coverage }\end{array}$ & -0.165 & 0.027 & Rabies Mortality $=2.065-0.015^{\star} \mathrm{ARV}$ Coverage & 0.279 \\
\hline Sex Ratio & 0.365 & 0.133 & Rabies Mortality $=-11.349+0,117^{\star}$ Sex Ratio & 0.0141 \\
\hline Education & -0.071 & 0.005 & Rabies Mortality $=1.356-0.433^{\star}$ Education & 0.642 \\
\hline Population Density & 0.046 & 0.002 & Rabies Mortality $=1.285+0.00^{\star}$ Population Density & 0.765 \\
\hline Health Workers Ratio & -0.345 & 0.119 & Rabies Mortality $=1.490-0.206^{\star}$ Health Workers Ratio & 0.0201 \\
\hline $\begin{array}{l}\text { Healthcare } \\
\text { Ratio }\end{array}$ & -0.320 & 0.103 & Rabies Mortality $=1.103-0.006^{\star}$ Healthcare Facility Ratio & 0.0322 \\
\hline
\end{tabular}

rabies mortality in 15 regencies/cities in North Sulawesi Province is shown in table 2.

In sex ratio variable (Figure 1), the negative pattern in the equation indicates that if there are more people who carry out anti-rabies vaccines, the rabies mortality will decrease. The coefficient of determination of 0.133 indicates that the regression line equation obtained can explain the $5 \%$ variation in the sex ratio or the line equation obtained can moderately explain the variable rabies mortality.

In the ratio of health workers variable (Figure 2), the negative pattern contained in the equation indicates that if there are more health workers available, the rabies mortality will be lower. The determination coefficient value of 0.119 indicates that the regression line equation obtained can explain $11.9 \%$ variation in the ratio of health personnel or the line equation obtained can moderately explain the variable rabies mortality.

In the ratio of health services variable (Figure 3), the negative pattern contained in the equation indicates that if there are more available health care facilities, the rabies mortality will be lower. The determination coefficient value of 0.103 indicates that the regression line equation obtained can explain $10.3 \%$ variation in the ratio of health service facilities or line equations obtained can moderately explain the variable

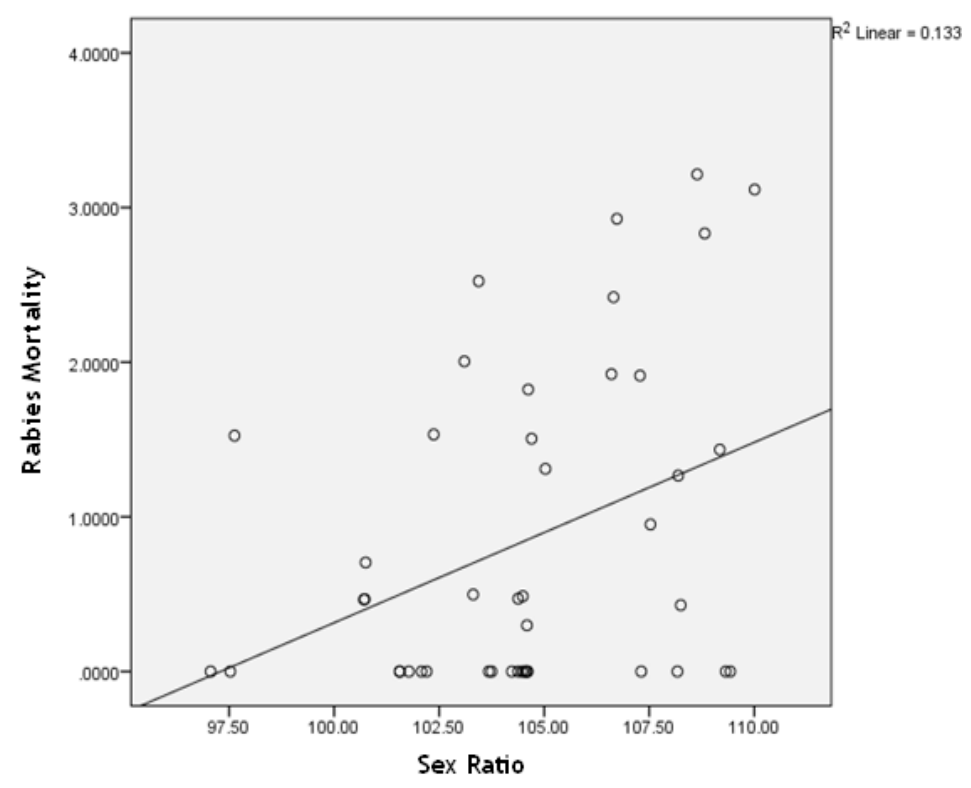

Figure 1. Scatter plot on Sex Ratio towards Rabies Mortality 


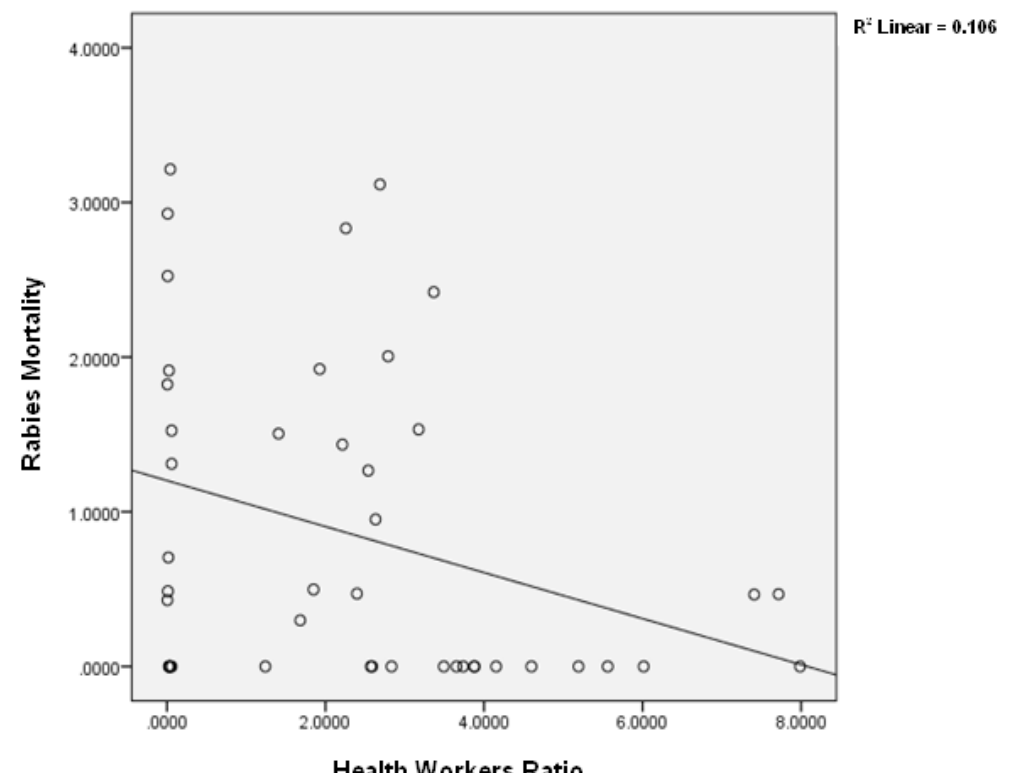

Figure 2. Scatter plot on Health Workers Ratio towards Rabies Mortality

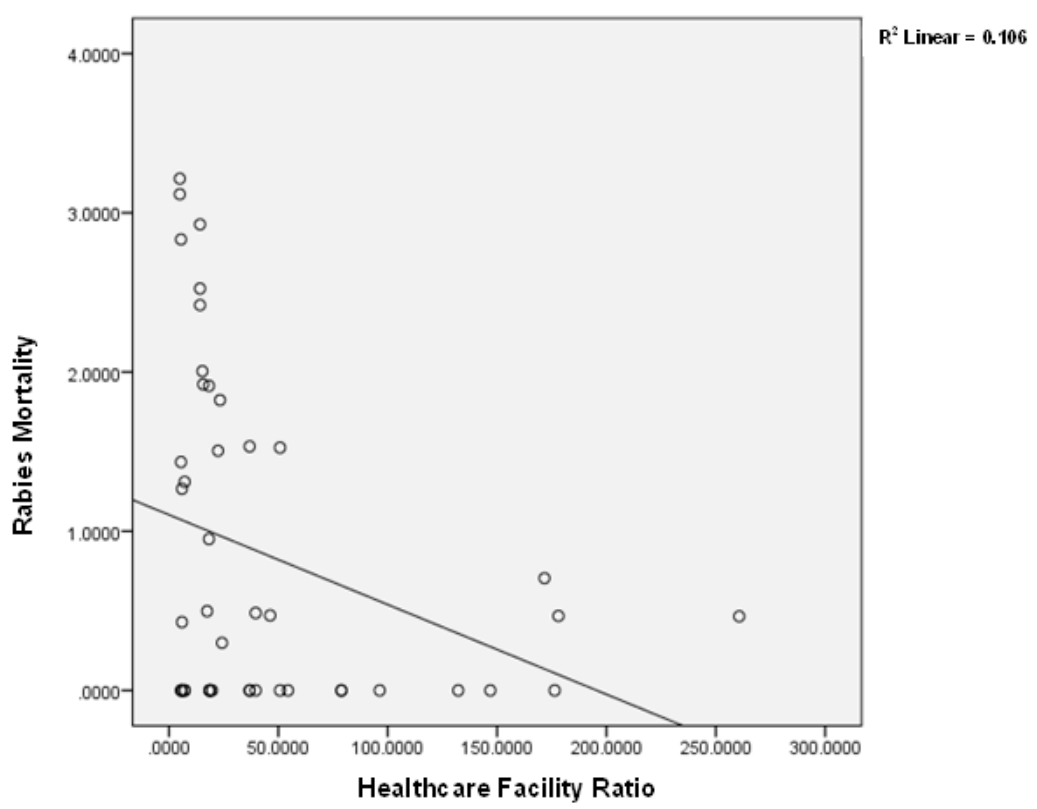

Figure 3. Scatter plot on Healthcare Facility Ratio towards Rabies Mortality

rabies mortality.

This study discusses factors which influences rabies mortality in North Sulawesi Province. Because of the limited data, we are limited in choosing variables that have a stronger possibility of predicting the incidence of rabies deaths, such as wound washing.

In this study, it was found that the anti-rabies vaccine had no correlation with a decrease in rabies mortality, but the statistically insignificant results were most likely due to an inadequate sample and a rare mortality rate. However, other studies have shown that there is a strong association with the use of the anti-rabies vaccine with a decrease in all causes of death in rabies, both due to the bite of domesticated dogs and wild dogs in South Africa over a 4-year period (Knobel, et al., 2017). The study found strong associations because it only included cofounding variables in the form of age and sex, not including the health status variable and previous vaccine use. 
However, this finding was supported by Conan, et al. (2015) who showed similar associations in South Africa after controlling for variables of age, sex, place of residence, including confounding variables.

Regarding population density and education variables, they had different correlation characteristics but these two variables did not show a significant relationship. However, in previous studies related to population density (Riley, John, \& David, 1998), it was revealed that places with high availability of food resources and shelter would increase the growth of rabies transmitting populations. A study held by Childs et al., (2010) shown that the biological factors of human population density and surveillance activities contribute to determining the size of the epizootic area, although rabies transmitting animal populations (especially raccoons) are the main determining factor. In term of education, the level of literation is significantly associated with the knowledge of rabies (Wasay, et al., 2012). The results of this study support other studies which explain that a person's knowledge of rabies will influence treatmentseeking behavior, including the acceptance of PEP vaccine (Barbosa Costa, et al., 2018). Also, having awareness of the dangers of animal bites transmitting rabies is really important to make someone immediately seek treatment (Krishnamoorthy, M, \& Sarkar, 2018).

Nevertheless, there were several variables that have significant relationship with $\mathrm{p}$-value of $<0.05$. The first variable was sex ratio. This finding showed that every male population increase per 100 female population would increase rabies deaths. This was in accordance with previous research carried out in China which showed that more cases of rabies were found in men compared to women. This was most likely associated with higher outdoor activities in men compared to women. Therefore, the risk of exposure to rabies transmitting animals is greater, especially in the slum area (Wang, et al 2010; Yin, et al, 2012; Montgomery, et al 2012).

Subsequent significant results were found in the variables of health personnel and facilities health services available in North Sulawesi Province. Health workers included in this study were every medical person except midwife. Every health worker is required to provide services in accordance with applicable standards, therefore they could support an increase in the provision of effective and safe health efforts. This is in accordance with a study conducted by Pan American Health Organization (PAHO) which facilitate the process of giving anti-rabies vaccines. Since 2016, PAHO has trained hundreds of professional health workers working in various health service facilities. The purpose was to guarantee that every healthcare personnel should be trained to be able to increase access to vaccine delivery and provide socialization to the public regarding the dangers of rabies (Pan American Health Organization, 2017)

In regards to health care facilities, we found that increase in availability of service facilities, will reduce the incidence of rabies mortality because it could facilitate the affected victims to get help (Zaidi, et al, 2013). This finding is in accordance with a study conducted in Central Africa in 2017 which found that the majority of death caused by rabies were associated with the failure to seek health services (Knobel DL, et al., 2005; Fooks ER, et al., 2014; Hampson K, et al., 2015). Unfortunately, not all health care facilities had anti-rabies vaccines. They, at least, able to perform one of the PEP activities, namely washing the wound for 15 minutes with a disinfectant. Then, the affected victim could be immediately referred to health care facilities that have rabies center.

It is necessary to emphasize that in this study, the correlation results, which were not statistically significant, do not mean that the result is contradicted to other studies. It could be caused by inadequate number of samples, which only came from 15 regencies/cities. This can be considered as limitation of this study.

In addition, this study cannot use individual data to see the relationship that happened, otherwise it could produce a phenomenon which is called ecological fallacy. The relationship could only be regarded as an association, therefore it could not be regarded as causal relationship.

\section{Conclusions}

According to the results of this study and compared to previous research regarding 
factors which affect rabies death, we conclude several answer to the research questions as follows.

The incidence of rabies in North Sulawesi

Province is fluctuating in 3 years period. Within 3 years, the average rabies mortality was 0.84 per 100,000 inhabitants. This meant that there were $0-1$ case of rabies death for every 100,000 residents in North Sulawesi. Based on correlation tests of the factors that influence the incidence of rabies death in North Sulawesi, there were 3 variables that had moderate strength in predicting the incidence of rabies death, namely sex ratio, ratio of health workers, and ratio of health service facilities to rabies deaths.

People who were more vulnerable to rabies, such as male gender, is also expected to be made as a target for prevention program against rabies. In view of the importance of service facilities and health workers, the local government should increase the number of health facilities and personnel by means of equal allocation according to the needs of the local regency/city.

\section{Acknowledgement}

The author would like to thank the Ministry of Health, Provincial Health Office of North Sulawesi, and Central Bureau of Statistics for their help with rabies surveillance data and other data that are needed for this study.

\section{References}

Barbosa Costa, G., Gilbert, A., Monroe, B., Blanton, J., Ngam Ngam, S., Recuenco, S., et al. (2018). The influence of poverty and rabies knowledge on healthcare seeking behaviours and dog ownership, Cameroon. PloS one.

Child, J. E., Curns, A. T., Dey, M. E., Real, L. A., Feinstein, L., Bjornstad, O. N., et al. (2000). Predicting the local dynamics of epizootic rabies among raccoons in the United States. National Academy of Sciences of the United States of America, 13666-13671.

Conan, A., Akerele, O., Simpson, G., Reininghaus, B., van Rooyen, J., \& Knobel, D. (2015). Population dynamics of owned, free roaming dogs: implications for rabies control. PLOS Neglected Tropical Diseases, 4177.

Fooks, A., Banyard, A., Horton, D., Johnson, N., McElhinney, L., \& Jackson, A. (2014). Current status of rabies and prospects for elimination. Lancet, 1389-1399.

Hampson, K., Coudeville, L., Lembo, T., Sambo, M.,
Kieffer, A., \& Attlan, M. (2015). Estimating the global burden of endemic canine rabies. PLoS neglected tropical diseases.

Kementerian Kesehatan RI. (2016). InfoDATIN Kementerian Kesehatan RI. Jakarta: Kementerian Kesehatan RI.

Kementerian Kesehatan RI. (2017). Buku Saku Petunjuk Teknis Penatalaksanaan Kasus Gigitan Hewan Penular Rabies di Indonesia. Jakarta: Kemenkes RI.

Kementerian Kesehatan RI. (2018, October 3). Rabies Penyakit Paling Mematikan di Dunia. Dipetik November 16, 2018, dari http://www.depkes. go.id/article/view/18100300005/rabiespenyakit-paling-mematikan-di-dunia.html

Knobel, D. L., Arega, S., Reininghaus, B., Simposin, G. J., Gessner, B. D., Stryhn, H., et al. (2017). Rabies vaccine is associated with decreased all-cause mortality in dogs,. Elsevier, 38443849.

Krishnamoorthy, Y., M, V., \& Sarkar, S. (2018). Awareness about rabies among general population and treatment seeking behaviour following dog-bite in rural Puducherry:a community based croess-sectional study. International Journal of Community Medicine and Public Health, 2558-2563.

Montgomery, J., Zhang, Y., Well, E., Liu, Y., Clayton , J., \& Wang, X. (2012). Human rabies in Tianjin, China. Journal of Public Health, 505511.

Pan American Health Organization. (2017). Brazil donates vaccines against human rabies to Haiti, with the support of Panaftosal PAHO. Dipetik December 22, 2018, dari PAHO.org: https://www.paho.org/hq/ index.php?option $=$ com_content $\&$ view $=\mathrm{a}$ rticle\&id=13427:brazil-donates-vaccinesagainst-human-rabies-to-haiti-support-ofpanaftosa-paho\&Itemid $=135 \&$ lang $=$ pt

Riley, S., John, H., \& David, M. (1998). Population density, survival, and rabies in raccoons in an urban national park. Canadian Journal of Zoology-revue Canadienne De Zoologie, X, 1153-64.

SEARO World Health Organization. (2012). Strategic Framework for Elemination of Human Rabies Transmitted by Dogs in South East Asian Region. New Delhi: SEARO WHO.

Tanzil, K. (2014). Penyakit Rabies dan Penatalaksanaanya. E-Journal Widya Kesehatan dan Lingkungan, I(1), 61-67.

Tenzin, Dhand, N., Gyeltshen, T., Firestone, S., \& Zangmo, C. (2011). Dog Bites in Humans and Estimating Human Rabies Mortality in Rabies Endemic Areas of Bhutan. PLOS 
Neglected Tropical Diseases.

Wang, X., Ding, S., Li, Z., Wang, L., Kou, Z., \& Feng, K. (2010). Human rabies epidemiology in Shandong Province. China Japan Journal of Infectious Disease, 323-326.

Wasay, M., Malik, A., Fahim, A., Yousuf, A., Chawla, R., Daniel, H., et al. (2012). Knowledge and attitudes about tetanus and rabies: a population-based survey from Karachi. Journal of Pakistan Medical Association, 62(4), 378-82.

World Health Organization. (2013). Rabies: General Introduction. Dipetik 12 2018, dari http://www.who.int/rabies/epidemiology/ Rabiessurveillance.pdf

Yin, C., Zhou, H., Wu, H., Tao, X., Rayner, S., \& Wang, S. (2012). Analysis on factors related to rabies epidemic in China from 2007-201. Virologica Sinica, 132-143.

Zaidi, S., Labrique, A., Khowaja, S., Lotia-Farrukh, I., Irani, J., \& Salahuddin, N. (2013). Geographic variation in access to dogbite care in Pakistan and risk of dog-bite exposure in Karachi:prospective surveillance using a low-cost mobile phone system. PLoS Neglected Tropical Disease, 2574. 